\title{
MANAJEMEN LEMBAGA SEMI OTONOM (LSO) PENDIDIKAN YAYASAN WIHDATUL UMMAH BATUSANGKAR DALAM MENINGKATKAN KUALITAS PENDIDIKAN DI SDIT QURRATA A'YUN BATUSANGKAR
}

\author{
Miftah Novi. T \\ Pegawai Kemenag Tanah Datar
}

120

\begin{abstract}
This study was qualitative and focused on the management of Semi Autonomous Institute (LSO) Wibdatul Ummah Batusangkar Foundation of Education in Improving the Quality of Education in SDIT Qurrata A'yun Batusangkar. The background of this research was the parents are more interested to educate their children in Islamic Elementary School (SDIT) Qurrata A'yun, meanwhile half of them are teachers in SD, SMP, MTs, SMA, MA and lecturer. The result revealed that the management of Semi Autonomous Institute was run well. LSO did the management based on the guide book The Management System of Semi Autonomous Institute 2013. LSO organized the program to upgrade the quality of education in every units. The programs were 1) Early Years Program; 2) Monthly Activity; 3) Weekly Activity; and 4) Daily Activity. Then organized the budget, developed facility and did monitoring and controlling.
\end{abstract}

Keywords: Management, Semi Autonomous Institute, Wihdatul Ummah Batusangkar Foundation, The Quality of Education

\section{PENDAHULUAN}

Kecendrungan Orang tua murid untuk menyerahkan anak-anak mereka belajar di Sekolah Dasar Islam Terpadu (SDIT) dalam beberapa dekade ini terus meningkat, meskipun tempat tinggal mereka cukup jauh dari sekolah dan mereka juga rela mengeluarkan biaya yang cukup besar. Hal ini sepadan dengan hasil yang mereka harapkan meskipun latar belakang pendidikan tenaga pendidik (guru) banyak yang tidak berlatar belakang ilmu keguruan, namun output alumni SDIT banyak yang diterima di sekolah favorit.

Maju mundurnya sebuah lembaga pendidikan, tak terlepas dari bagaimana pengelola sekolah tersebut melaksanakan tugas, fungsi, dan tanggung jawabnya dalam meningkatkan kualitas sumber daya manusia. Kemudian memberikan pelayanan kepada masyarakat dan menyelenggarakan pendidikan secara berkesinambungan. 
Pendidikan di Sekolah Dasar Islam Terpadu (SDIT) umumnya dikelola oleh yayasan yaitu badan hukum yang terdiri atas kekayaan yang dipisahkan dan diperuntukan untuk mencapai tujuan tertentu di bidang sosial, keagamaan dan kemanusiaan, yang tidak mempunyai anggota (UU No.16 Tahun 2001). Pendirian suatu yayasan di Indonesia, sebelum adanya undang-undang, yayasan hanyalah berdasarkan kebiasaan dalam masyarakat dan yurisprudensi Mahkamah Agung. Pada waktu itu ada kecendrungan masyarakat memilih bentuk yayasan antara lain karena 1) proses pendiriannya sederhana, 2) tanpa pengesahan dari pemerintah, dan 3) adanya persepsi dari masyarakat bahwa yayasan bukan merupakan subyek pajak (Setiawan, 1992).

Sebenarnya draf undang-undang mengenai yayasan telah tersimpan di Departemen Kehakiman sejak tahun 1976, namun baru terealisasi setelah adanya peran International Monetary Fund (IMF) melalui Letter of Intent (Memorandum of Economic and Financial Policies Medium Term Strategy and Policies for 1999/2000 - 2000, tanggal 20 Januari 2000). LoI ini mensyarat-kan pemberlakuan undang-undang mengenai yayasan sebagai salah satu klausul yang harus dipenuhi oleh pemerintah Indonesia untuk mendapatkan bantuan keuangan dari IMF.

Menindaklanjuti Letter of Intent tersebut, maka pada tanggal 6 Agustus
2001 , pemerintah mengundangkan Undang-undang Republik Indonesia Nomor 16 Tahun 2001 tentang Yayasan. Berdasarkan pasal 11 ayat (1) UU No. 16 Tahun 2001, maka status badan hukum yayasan yang semula diperoleh dari sistem terbuka penentuan suatu badan hukum (het Open Systeem van Rechts-personen) yang berlandaskan pada kebiasaan, doktrin, dan ditunjang yurisprudensi, beralih pada sistem tertutup (de Gesloten systeem van Rechtspersonen) sehingga yayasan menjadi badan hukum karena atau berdasarkan undang-undang (Chatamarrasjid, 2000).

Menindak lanjuti hal tersebut agar tercapainya tujuan yayasan maka pemerintah mengundangkan Undang-undang Republik Indonesia Nomor 28 Tahun 2004 tentang Perubahan Atas Undang-Undang No. 16 Tahun 2001 tentang yayasan tujuannya adalah untuk lebih menjamin kepastian dan ketertiban hukum serta memberikan pemahaman yang benar kepada masyarakat mengenai yayasan (UU No. 28 Tahun 2004). Secara garis besar, berdasarkan Undang-Undang No. 28 Tahun 2004 dapat dipahami bahwa peran yayasan dalam mengelola lembaga pendidikan antara lain sebagai 1) penyelenggara dan penanggung jawab sekolah secara hokum; 2) penentu visi, orientasi, platform program dan kebijakan dasar sekolah; 3) pemberi mandat dan 
tanggung jawab pengelola sekolah; 4) penyedia sarana, prasarana dan pembiayaan sekolah; dan 5) pengendali pengelolaan sekolah.

Meskipun peran dan fungsi yayasan sangat penting dan startegis dalam menentukan maju mundurnya sebuah lembaga pendidikan, namun di lapangan seringkali ditemukan perbedaan antara teori dengan kenyataan, sebagai contohnya pengelolaan sekolah/madrasah swasta seringkali dihadapkan pada konflik internal yang tidak berkesudahan antara pengurus yayasan dengan kepala sekolah/madrasah, yang tidak jarang kian membuat nasib sekolah terpuruk. Terjadinya konflik tersebut umumnya dikarenakan ketidakjelasan struktur kelembagaan, status, peran atau fungsi setiap pihak yang menjadi tulang punggung pengelolaan (stakeholders) sekolah/madrasah tersebut.

Dalam kasus lain susunan pengurus lengkap namun program tidak ada, program ada namun hanya di atas kertas, bergerak ketika ada momen-momen tertentu, arti kata yayasan hanya sebagai simbol saja. Bahkan status yayasan bersifat "mengamini" saja tidak memiliki ide atau program kerja. Apa yang diprogramkan oleh kepala sekolah secara otomatis langsung menjadi program yayasan, artinya yayasan seperti ini hanya "mengekor" apa yang diprogramkan oleh kepala sekolah. Di lain pihak ada juga yayasan yang bersifat otoriter sehingga pihak sekolah berlaku pasif.

Oleh karena itu, agar yayasan bisa berperan secara optimal, efektif dan efesien dalam mengelola lembaga yang dinaunginya, seyogyanya semua pihak memahami status, peran dan fungsi masing-masing. Berdasarkan hasil survei awal yang peneliti lakukan di SDIT Qurrata A'yun Batusangkar, ternyata Yayasan Wihdatul Ummah Batusangkar yang menaungi SDIT Qurrata A'yun Batusangkar telah melakukan pembagian tugas dan fungsi secara profesional, bahkan pengurus yayasan melakukan terobosan dengan membentuk Lembaga Semi Otonom (LSO) Pendidikan yang diberi wewenang penuh untuk mengelola unit pendidikan. Hal ini dilakukan sebagai upaya yayasan mewujudkan manajemen yayasan sebagai Lembaga yang profesional, modern, transparan dan akuntabel dalam mengelola lembaganya.

\section{MANAJEMEN}

Manajemen adalah ilmu dan seni yang mengatur proses pemanfaatan sumber daya manusia dan sumber-sumber lainnya secara efektif dan efisien untuk mencapai suatu tujuan tertentu (Hasibuan, 1990). Kayo (2007) mendefinisikan bahwa manajemen itu adalah kemampuan 
dan keterampilan seseorang untuk merencanakan, mengatur dan mengelola, serta mengawasi jalannya suatu kegiatan atau program, sehingga secara optimal dapat mencapai tujuan yang dinginkan dengan tepat waktu dan tepat sasaran. Sedangkan menurut Terry manajemen sebagai " $a$ distinct process consisting of planining, organizing, actuanting, and controlling performed to determine and acomplish stated objectives by the use of humen being and other resources" (Hasibuan, 1990). Hanafi (2000) berpendapat bahwa manajemen adalah perencanaan (planning), pengorganisasian (organizing), penyusunan personalia (staffing), pengawasan dan pengendalian (controlling). Sedangkan menurut Pidarta (1998) manajemen ialah proses mengintegrasikan sumber-sumber yang tidak berhubungan menjadi sistem total untuk menyelesaikan suatu tujuan, yang dimaksud sumber di sini ialah mencakup orang orang, alat-alat media, bahan-bahan, uang dan sarana. Semuanya diarahkan dan dikoordinasi agar terpusat dalam rangka menyelesaikan tujuan. Sedangkan dalam pedidikan diartikan manajemen sebagai aktivitas memadukan sumbersumber pendidikan agar terpusat dalam usaha mencapai tujuan pendidikan yang telah ditentukan sebelumnya. Manajemen merupakan faktor utama dan memiliki andil dalam mencapai tujuan lembaga berupa pengorganisasian, pengkoordinasian dan pengawasan terhadap personalia, finansial, sarana prasarana, media, dan informasi sesuai dengan kerangka kerja manajemen, yakni membuat perencanaan, pengaturan, pengarahan, dan pengawasan.

\section{MANAJEMEN PENDIDIKAN}

Menurut Mulyasa (2005) manajemen pendidikan merupakan proses pengembangan kegiatan kerja sama sekelompok orang untuk mencapai tujuan pendidikan yang telah ditetapkan. Proses pengendalian kegiatan tersebut mencakup perencanaan (planning), pengorganisasian (organizing), penggerakan (actualiting) dan pengawasan (controlling), sebagai suatu proses untuk menjadikan visi menjadi aksi.

Manajemen pendidikan adalah sebagai seni dan ilmu mengelola sumber daya pendidikan untuk mewujudkan suasana belajar dan proses pembelajaran agar peserta didik secara aktif mengembangkan potensi dirinya untuk memiliki kekuatan spiritual keagamaan, pengendalian diri, kepribadian, kecerdasan, akhlak mulia, serta ketrampilan yang diperlukan dirinya, masyarakat bangsa dan Negara (Usman, 2006). Dapat juga diartikan manajemen pendidikan merupakan rangkaian 
kegiatan bersama atau keseluruhan proses pengendalian usaha atas kerja sama. Sekelompok orang dalam mencapai tujuan pendidikan yang telah ditetapkan secara berencana dan sistematis, yang diselenggarakan pada suatu lingkungan tertentu manajemen pendidikan pada hakekatnya menyangkut tujuan pendidikan, manusia yang melakukan kerja sama, proses sistemik dan sistematik, serta sumbersumber yang didayagunakan (Mulyasa, 2005). Sebagai suatu tujuan yang telah ditetapkan tentunya manajemen mempunyai suatu langkah yang sistemik dan sistematik dalam mencapai suatu tujuan yang ingin dicapai. Dalam arti yang lebih luas manajemen juga bisa disebut sebagai pengelolaan sumber-sumber baik sumber daya manusia maupun non sumber daya manusia guna mencapai suatu tujuan yang telah ditetapkan, karenanya manajemen ini memegang peranan yang sangat urgen dalam dunia pendidikan.

\section{LEMBAGA SEMI OTONOMI (LSO) PENDIDIKAN}

Lembaga Semi Otonomi (LSO) Pendidikan ini adalah bagian dari organ struktur Yayasan Wihdatul Ummah Batusangkar yang dibentuk pada tahun 2005, dengan tujuan agar pendidikan yang dikelola oleh Yayasan Wihdatul Ummah benar-benar efektif dan efesien. Yayasan memberikan tanggung jawab penuh kepada LSO Pendidikan untuk mengelola bidang pendidikan dan yayasan tidak ikut campur dalam manajemennya.

Ketua LSO Pendidikan Yayasan Wihdatul ummah menyebutkan bahwa "yayasan memberikan tanggungjawab penuh kepada LSO Pendidikan untuk mengelola bidang pendidikan dan yayasan tidak ikut campur dalam pelaksanaan manajemennya, dengan arti kata LSO Pendidikan Wihdatul Ummah memiliki independen atau kebebasan dalam mengambil keputusan dan merumuskan kebijakan yang menyangkut perencanaan, pengelolaan administrasi, keuangan, sumberdaya (manusia, dana, sarana, dan prasarana) dan berkewajiban membuat laporan atau mempertanggungjawabkan kondisi, perkembangan, proses dan hasil pelaksanaan program kepada pengurus yayasan WU, kecuali yang berhubungan dengan pengembangan atau hal-hal strategis, contoh pembangunan Gedung, pembelian tanah, atau untuak pendirian SMPIT, itu tanggung jawab yayasan".

Senada dengan itu, Ketua Yayasan Wihdatul Ummah menyebutkan "karena pendidikan itu perlu penanganan khusus, maka yayasan berinisiatif membetuk lembaga yang khusus mengelola bidang pendidikan, tetapi bidang pendidikan tersebut bersifat otonom, sifatnya independen, tetapi lembaga tersebut bertanggungjawab langsung kepada 
ketua yayasan, nah begitu pentingnya LSO Pendidikan tersebut. Nah, kalau LSO, memang punya wewenang penuh dalam pengelolaan pendidikan tetapi tetap ada batas kewenagan tersebut, misalnya dalam pengangkatan kepala sekolah, pengangkatan guru, pemberhentian guru, penetapan biaya operasional sekolah, masalah pembangunan, pengadaan tanah itu wewenang yayasan “. Sekarang, LSO Pendidikan mengayomi tiga lembaga pendidikan yakni Pendidikan Usia Dini (PAUD) Taman Asuh Anak Islam, Taman Kanak Kanak Islam (TKAI) Qurrata A'Yun, dan Sekolah Dasar Islam Terpadu (SDIT) Qurrata A'yun.

\section{PENINGKATAN MUTU (KUALITAS)}

Sejalan dengan hal tersebut manajemen mutu juga merupakan konsep dalam upaya peningkatan kualitas pendidikan. Berbagai upaya tersebut dapat terlihat dari lahirnya kajian teoritik mengenai mutu pendidikan, seperti manajemen mutu terpadu dalam pendidikan (Total quality management in education), jaminan mutu dalam pendidikan (Quality assurance in education), Gugus kendali mutu, Manajemen peningkatan mutu berbasis lembaga pendidikan, dan lain sebagainya. Perkembangan konsep tersebut merupakan suatu hal yang menggembirakan, karena hal tersebut menunjukkan adanya keseriusan untuk memikirkan bagaimana kualitas pendidikan dapat dicapai (Mulyasa, 2005).
Pengertian kualitas atau mutu secara umum adalah gambaran dan karakteristik yang menyeluruh dari barang-barang dan jasa yang menunjukkan kemampuannya dalam memenuhi kebutuhan yang ditentukan dalam konteks pendidikan. Pengertian mutu mencakup input, proses dan output pendidikan (Depdiknas, 2012). Untuk menjadikan lembaga pendidikan agama dan keagamaan (seperti Sekolah Dasar Islam Terpadu) yang berkualitas, maka menurut Afifuddin (2010) aspek suatu lembaga pendidikan/sekolah dipersyaratkan mempunyai standar mutu pula, antara lain aspek administrasi/manajemen, aspek ketenagaan, aspek kesiswaan, aspek kultur belajar, dan aspek sarana prasarana.

Pendidikan merupakan tanggung jawab bersama yang saling mengisi dari segenap Semua komponen baik pemerintah, penyelenggara/pengelola sekolah maupun masyarakat. Mayarakat akan menjadi tumpuan terhadap peningkatan dan pelayanan kualitas pendidikan yang diselenggarakan oleh lembaga pendidikan, hubungan yang harmonis antara lembaga pendidikan dengan masyarakat akan memberikan dampak yang berarti bagi peningkatan kualitas pendidikan.

Lembaga pendidikan dan masyarakat merupakan dua komunitas yang saling melengkapi antara satu denagan yang 
lainnya, bahkan ikut memberikan warna terhadap perumusan model pembelajaran tertentu melalui ide-ide atau bantuan yang diwujudkan melalui tenaga atau bantuan finansial dan jasa. Artinya lembaga pendidikan merupakan bagian yang tidak terpisahkan dengan masyarakat, bahkan lembaga pendidikan tumbuh dan berkembang sesuai denagan tuntutan, kebutuhan dan harapan masyarakat.

Di lain pihak ada lembaga pendidikan yang menempatkan masyarakat hanya sasaran yang strategis bagi lembaga dalam mengambil keuntungan finansial. Pengelolaan lembaga seperti ini akan mengakibatkan masyarakat kecewa dan enggan menyekolahkan anak mereka di lembaga tersebut. Oleh sebab itu hubungan atau komunikasi antara lembaga pendidikan dengan masyarakat harus selalu dijaga dengan baik, sebab masyarakatpun dapat mengetahui dan memahami kebutuhan dan kegiatan lembaga pendidikan, sehingga masyarakat terdorong untuk bekerjasama dalam upaya meningkatkan dan mengembangkan kuantitas namun tetap mengacu pada kualitas.

\section{METODE PENELITIAN}

Jenis penelitian yang peneliti gunakan adalah penelitian kualitatif dengan pendekatan fenomenologis (Ritzer, 2007).
Pendekatan fenomenologis digunakan untuk mencari atau menemukan makna dari hal-hal yang esensial atau mendasar dari pengalaman hidup berkenaan dengan konsep, pendapat, pendirian, sikap, penilaian, dan pemberian makna terhadap situasi atau pengalaman-pengalaman dalam kehidupan (Sukmadinata, 2009). Jadi, hasil penelitian ini dapat meningkatkan pemahaman para pembaca tentang makna yang terdapat dalam pengalaman hidup manusia baik individunya maupun pengalaman manusia secara berkelompok dalam mengelola lembaga termasuk lembaga pendidikan.

Pada penelitian ini sumber data dapat diklasifikasikan menjadi dua bagian, yaitu sumber data primer dan sekunder. Sumber data primer dalam penelitian ini adalah Ketua Lembaga Semi Otonom (LSO) Pendidikan dan Ketua Yayasan Wihdatul Ummah Batusangkar. Sumber data sekunder dalam peneliti ini adalah, kepala sekolah, Guru, karyawan, dan masyarakat di sekitar SDIT Qurrata 'Ayun. Pemilihan informan dalam penelitian ini adalah dengan teknik snowballsampling yaitu informan kunci akan menunjuk orang yang mengetahui masalahmasalah yang akan diteliti untuk melengkapi keterangan-keterangan dan orang yang ditunjuk akan menunjuk orang lain bila keterangan yang diberikan kurang bisa dipahami dan seterusnya. Teknik ini akan 
bermanfaat bagi peneliti sebagai validitasi data yang diberikan oleh informan.

Untuk mendapatkan data-data yang valid dalam mengumpulkan data yang dibutuhkan, peneliti menggunakan teknik pengumpulan data wawancara, observasi, dan studi dokumen. Wawancara dilakukan untuk mengetahui atau mendapatkan keterangan tentang kejadian dan kegiatan yang sesungguhnya tentang pelaksanaan manajemen yang dilakukan oleh LSO Pendidikan Yayasan Wihdatul Ummah Batusangkar.

Teknik wawancara terdiri dari tiga jenis yaitu wawancara terstruktur (structured interview), wawancara semi terstruktur (semistructured interview), dan wawancara tidak terstruktur (unstructured interview). Wawancara terstruktur (structured interview) adalah wawancara yang dilakukan sesuai dengan pedoman penelitian, apabila muncul kejadian di luar pedoman tersebut maka hal itu tidak dihiraukan (Sukandarrumidi, 2006). Wawancara semi terstruktur (semistructured interview) adalah wawancara yang dilakukan dengan mengembangkan instrumen penelitian. Wawancara ini sudah termasuk dalam katagori wawancara mendalam yang pelaksanaannya lebih bebas dan terbuka dibandingkan wawancara terstruktur. Wawancara mendalam yang sebenarnya adalah jenis wawancara yang ketiga.
Oleh karena itu, wawancara mendalam sering disebut juga dengan wawancara tidak terstruktur. Dalam penelitian ini peneliti menggunakan jenis wawancara Semi terstruktur/wawancara mendalam (semistructured interview) dan Wawancara tidak terstruktur (unstructured interview). Hal ini penting untuk dijelaskan mengingat penelitian ini berusaha mencari pendapat, motivasi persepsi, pengalaman, dan hal-hal yang khas lainnya yang bersifat alamiah.

Observasi yang dilakukan dalam penelitian ini adalah observasi partisipatoris (participation observasion). Alasan dilakukannya observasi partisipatoris sebagai instrument penelitian kualitatiffenomenologi. Tahap observasi yang peneliti lakukan 1) observasi pendahuluan dalam riset awal; dan 2) observasi terlibat selama waktu tertentu sebelum dan sesudah seminar proposal tesis. Kegiatan observasi yang dilakukan adalah melihat dan mengamati aktivitas Manajemen LSO Pendidikan Yayasan Wihdatul Ummah Batusangkar dalam meningkatkan kualitas pendidikan di SDIT Qurrata A'yun Batusangkar.

Studi Dokumen yang dilakukan adalah menelaah catatan, dokumentasi dan menelusuri peristiwa menyangkut pelaksanaan manajemen yang dilakukan oleh LSO Pendidikan Yayasan Wihdatul Ummah dalam meningkatkan kualitas pendidikan 
di SDIT Qurrata A'yun Batusangkar. Demi terjaminnya akurasi data yang didapatkan dari dokumen maka peneliti melakukan tiga telaahan sebagaimana yang diterapkan oleh Direjo (2005) yaitu 1) keaslian dokumen yang didapat; 2) kebenaran isi dokumen; dan 3) relevansi isi dokumen dengan permasalahan yang dikaji dalam penelitian. Dalam penlitian ini dokumentasi adalah suatu cara untuk mengetahui sesuatu dengan melihat catatan-catatan, arsip-arsip, dokumen-dokumen, yang berhubungan dengan Manajemen LSO Pendidikan Yayasan Wihdatul Ummah Batusangkar dalam meningkatkan kualitas pendidikan di SDIT Qurrata A'yun Batusangkar, serta data-data lain yang terkait dengan variabel penelitian.

Analisis data dalam penelitian ini dilakukan secara interaktif dan berlangsung secara terus menerus sampai tuntas hingga datanya jenuh. Analisis data dilakukan melalui 3 tahap, yaitu reduksi data; penyajian data; dan kesimpulan (Rohendi, 1992).

\section{HASIL PENELITIAN DAN PEMBAHASAN}

LSO Pendidikan Yayasan Wihdatul Ummah Batusangkar telah melaksanakan fungsi manajemen. Berpedoman kepada buku panduan Sistem Manajemen Tata Kelola LSO Pendidikan (sekarang yang digunakan Sistem Manajemen Tata Kelola Lembaga Semi
Otonom (LSO) Pendidikan Tahun 2013) dibuat sebagai standar pengelolan lembaga secara umum, mulai dari proses perencanaan, pengorganisasian, pelaksanaan program sampai kepada pengawasan yang memuat tentang alur pengelolan Sumber Daya Manusia, pengembangan sarana prasana, serta pembiayaan, semuanya disusun secara sistematis dan terstruktur. Buku panduan tersebut juga memuat alur dan tahapan kerja yang jelas pada setiap unit lembaga yang disebut sebagai Standar Operasional Prosedur (SOP) yang menjadi rujukan setiap SDM dalam menunaikan amanah yang diberikan kepadanya dalam rangka mewujudkan sistem birokrasi yang efektif dan efesien dan memiliki dasar hukum yang jelas di Lembaga Semi Otonom (LSO) Pendidikan Yayasan Wihdatul Ummah. Dengan adanya buku tersebut, maka dalam membuat perencanaan dapat memudahkan LSO Pendidikan menyusun program dan pengorganisasian guna meningkatkan kualitas pendidikan dimasing-masing unit.

\section{PERENCANAAN PROGRAM LSO PENDIDIKAN YAYASAN WIHDATUL UMMAH}

Keberadaan Lembaga Semi Otonom (LSO) pendidikan sebagai ujung tombak Yayasan Wihdatul Ummah dalam mengelola pendidikan sangat berpengaruh besar 
terhadap perkembangan unit-unit pendidikan yang berada di bawah naungan Yayasan Wihdatul Ummah. Agar LSO pendidikan dan unit-unit pendidikan yang berada dalam tanggung jawab LSO pendidikan itu bergerak dan berkembang secara profesional, efektif dan efesien maka disusunlah Buku Panduan Sistem Manajemen Tata Kelola LSO Pendidikan sebagai standar pengelolan lembaga secara umum, mulai dari proses perencanaan, pengorganisasian, pelaksanaan program sampai kepada pengawasan yang memuat tentang alur pengelolan Sumber Daya Manusia, pengembangan sarana prasana, serta pembiayaan, semauanya disusun secara sistematis dan terstruktur (LSO Pendidikan, 2013).

Buku panduan tersebut juga memuat alur dan tahapan kerja yang jelas pada setiap unit lembaga yang disebut sebagai Standar Operasional Prosedur (SOP) yang menjadi rujukan setiap SDM dalam menunaikan amanah yang diberikan kepadanya dalam rangka mewujudkan sistem birokrasi yang efektif dan efesien dan memiliki dasar hukum yang jelas di Lembaga Semi Otonom (LSO) Pendidikan Yayasan Wihdatul Ummah. Dengan adanya buku panduan tersebut, maka dalam membuat perencanaan memudahkan LSO pendidikan menyusun program dan pengorganisasian guna meningkatkan kualitas pendidikan di masing-masing unit. Program kerja tahunan tersebut meliputi 1) Program Awal Tahun; 2) Kegiatan Bulanan; 3) Kegiatan Mingguan; dan 4) Kegiatan Harian.

Sebelum dilaksanakan rapat tahunan maka terlebih dahulu Kepala Sekolah bersama majelis guru dan pegawai masingmasing unit menyusun Rencana Kerja Tahunan Sekolah (RKTS) sekaligus Rancangan Anggaran Biaya (RAB) yang dibutuhkannya untuk diajukan ke Ketua LSO pendidikan. Di samping program yang sudah direncanakan oleh LSO pendidikan, RKTS dan RAB masingmasing unit juga menjadi pedoman bagi LSO pendidikan dalam menyusun Rencana Kerja Tahunannya. Rencana kerja yang telah dirumuskan oleh LSO pendidikan atas persetujuan Ketua Yayasan selanjutnya disosialisasikan oleh Pengurus LSO kepada masing masing unit, sehingga maksud dan tujuan yang telah ditetapkan oleh LSO dapat dipahami dan dilaksanakan oleh seluruh SDM terkait.

\section{PENGORGANISASIAN LSO PENDIDIKAN}

Agar tujuan yayasan bisa terlaksana, maka untuk mengatur dan menjalankannya sangat penting adanya pembagian tugas dan tanggung jawab sehingga masingmasing unsur bisa menjalankan fungsi secara dinamis, efektif, dan efesien. Struktur 
Pengorganisasian LSO Pendidikan Yayasan Pendidikan dan Dakwah Wihdatul Ummah Batusangkar adalah sebagai berikut.

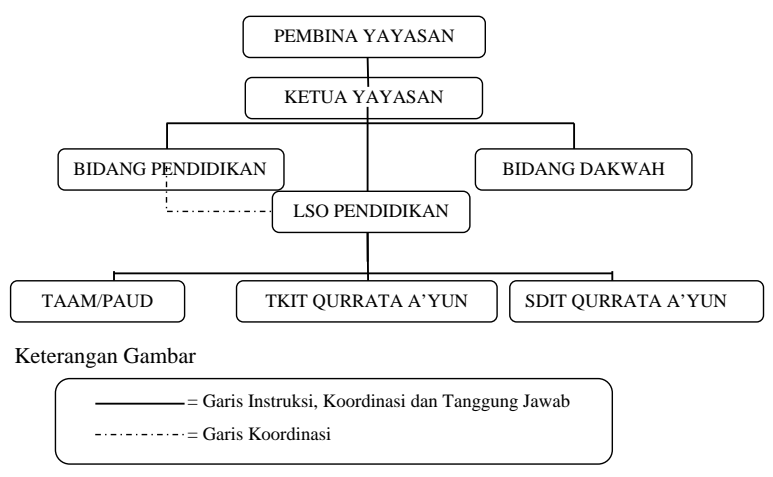

\section{PENYUSUN BIAYA OPERASIONAL (ANGGARAN)}

Pembiayaan adalah salah satu penopang kelancaran kegiatan sebuah lembaga, kecil atau besarnya dana sebuah lembaga jika disusun secara profesional maka lembaga akan berjalan sebagaimana yang diinginkan. Rencana Anggaran Biaya (RAB) merupakan rencana perolehan pembiayaan pendidikan dari berbagai sumber pendapatan serta susunan program kerja tahunan yang terdiri dari sejumlah kegiatan rutin serta beberapa kegiatan lainnya disertai rincian rencana pembiayaannya dalam satu tahun anggaran. Dengan demikian RAB berisi tentang ragam sumber pendapatan dan jumlah nominalnya baik rutin maupun pembangunan, ragam pembelanjaan dan jumlah nominalnya dalam satu tahun anggaran. RAB adalah sebuah langkah dalam menentukan kebijakan pembiayaan yang bersumber pada pendanaan pendidikan baik dalam internal maupun eksternal guna mendukung pelaksanaan pendidikan di sekolah.

\section{PENGEMBANGANSARANA PRASARANA}

Administrasi sarana dan prasarana sekolah merupakan tindakan yang dilakukan secara periodik dan terencana untuk merawat fasilitas fisik, seperti gedung, mebel, dan peralatan sekolah lainnya, dengan tujuan untuk meningkatkan kinerja, memperpanjang usia pakai, menurunkan biaya perbaikan dan menetapkan biaya efektif perawatan sarana dan prasarana SDIT Qurrata A'yun Batusangkar. Secara sederhana, administrasi sarana dan prasarana pendidikan dapat didefinisikan sebagai proses kerjasama pendayagunaan semua sarana dan prasarana pendidikan secara efektif dan efisien. Sedangkan jenis-jenis prasarana pendidikan di SDIT Qurrata A'yun Batusangkar bisa diklasifikasikan menjadi dua macam, yaitu pertama, prasarana pendidikan yang secara langsung digunakan untuk proses belajar mengajar, seperti ruang teori, ruang perpustakaan, ruang praktek keterampilan, dan ruang laboratorium. Kedua, prasarana sekolah yang keberadaannya tidak digunakan untuk proses belajar mengajar, tetapi secara langsung sangat menunjang terjadinya 
proses belajar mengajar. Beberapa contoh tentang prasarana sekolah jenis terakhir tersebut di antaranya adalah ruang kantor, kantin sekolah, tanah dan jalan menuju sekolah, kamar kecil, ruang usaha kantin sekolah, ruang guru, ruang kepala sekolah, dan tempat parkir kendaraan.

\section{PENGAWAS DAN PENGENDALI PROSES PENGELOLAAN SEKOLAH}

Suatu Pengawasan dikatakan penting karena Tanpa adanya pengawasan yang baik tentunya akan menghasilkan tujuan yang kurang memuaskan, demikian pula dengan pengendalian. Proses pengawasan dan pengendalian saling keterkaitan dengan proses-proses yang lain terutama dalam perencanaan. Kegiatan pengawasan dan pengendalian merupakan proses akhir dari proses manajemen. Tiga bentuk pengawasan yang dilakukan LSO pendidikan Yayasan Wihdatul Ummah antara lain 1) menyusun perencanaan program; 2) mengukur kinerja; dan 3) evaluasi dan perbaikan.

Dalam penyususunan perencanaan program tahunan merupakan tolak ukur bagi LSO pendidikan untuk melakukan pengawasan terhadap pengelolan SDIT Qurrata A'yun. Perencanaan Program tergambar dalam Rencana Kerja Kepala sekolah dan sekaligus dalam Rencana Anggran Belanja (RAB) SDIT Qurrta A'yun untuk satu tahun kedepan. Jadi langkah pertama dalam proses pengawasan adalah menyusun rencana program.

Dalam pengawasan yang dilakukan LSO pendidikan adalah mengukur atau mengevaluasi kinerja yang telah disusun dalam perencanaan program yakni bagaimana proses pelaksanaan capaian kinerja dan sejauhmana pelaksanaannya dilakukan oleh Kepala sekolah dan seluruh personil di SDIT Qurrata A'yun. Proses pengawasan tidak lengkap jika tidak ada tindakan perbaikan terhadap hambatan atau kendala-kendala yang terjadi. Dengan adanya pengukuran kinerja, maka setiap hambatan akan dilakukan evaluasi sekaligus dicarikan solusinya agar tujuan dapat tercapai sebagaimana yang telah disusun diawal perencanaan program.

Pengawasan yang dilakukan oleh LSO pendidikan Yayasan Wihdatul Ummah terhadap penyelenggara SDIT Qurrata A'yun Batusangkar adalah melalui pengontrolan harian dan penilaian kinerja terhadap program-program yang telah direncanakan. Kepala Sekolah merupakan pemimpin pendidikan, yang bertugas mengatur semua sumber organisasi karena kepala sekolah berhubungan langsung dengan pelaksanaan program pendidikan di sekolah dan bekerja sama dengan guru-guru dalam mendidik siswa untuk mencapai tujuan pendidikan. 
LSO pendidikan memberikan wewenang seluas-luasnya kepada Kepala Sekolah beserta perangkatnya untuk berkreasi dan mengelola bidang pendidikan dengan arti kata tidak mengintervensi, namun tetap mengawasi. Dengan arti kata terhadap SDIT Qurrata A'yun LSO tidak mencampuri tugas dan tanggung jawab Kepala Sekolah tugas dan fungsinya sebagai manager, selagi berada dalam sistem dan tata kelola yang telah ditetapkan, namun Kepala Sekolah berkewajiban memberikan laporan kepada Ketua LSO pendidikan tentang perkembangan sekolah yang dikelolanya. Sebagus apapun rencana atau program yang disusun, dalam aplikasinya tetap ada hambatan-hambatan yang dilalui, namun dengan memahami tugas dan fungsi masing-masing, saling koordinasi, adanya pengawasan dan evaluasi bagi manajer menjadikan dinamika tersebut sebagai peluang.

Untuk mengahadapi kejenuhan dan kelemahan yang ada di SDIT Qurrata A'yun, LSO pendidikan dan Kepala Sekolah meningkatkan kopetensi dan wawasan tenaga pendidik dan kependidikan dalam melaksanakan dan menjalankan fungsi dan kewajibannya. Kemudian LSO pendidikan Yayasan Wihdaul Ummah Batusangkar mengadakan pelatihan-pelatihan, di antaranya adalah 1) pelatihan dari TPK
(Tim Pengembang Kurikulum) Propinsi, materi yang diberikan adalah terkait dengan kurikulum SIT dan hal-hal lainnya untuk meningkatkan karakter yang berciri khas SIT. Pelatihan dari TPK propinsi ini dilakukan sesuai dengan kebutuhan; 2) pelatihan dari Litbang Yayasan, yang dilakukan sekali dalam satu semester. Para personalia Litbang senantiasa berupaya untuk melakukan pelatihan-pelatihan untuk para guru. Tematema yang dibahas oleh pemateri dalam pelatihan ini lebih menekankan pada aspek kurikulum dan perangkat pembelajaran. Sehingga di dalam proses pembelajaran para guru tidak mengalami kesulitan; 3) Melakukan training-training kependidikan seperti pelatihan atau workshop penyusunan perangkat pembelajaran, mengadakan pelatihan dan diskusi tentang perkembangan pendidikan, melakukan pembinaan teknikteknik, metode mengajar serta media pembelajaran yang efektif; 4) briefing atau rapat mingguan yang dilakukan satu kali dalam satu minggu yang rutin dilakukan pada hari sabtu. Semua guru diwajibkan untuk mengikuti briefing. Tujuannya setiap ada permasalahan dibicarakan dan dicarikan jalan keluar secara bersama-sama; dan 5) mengadakan kajian mingguan untuk para guru dan orang tua murid. Setiap guru SDIT Qurrata A'yun Batusangkar diwajibkan mengikuti kajian mingguan. Kajian 
mingguan ini bertujuan untuk menambah wawasan keisalaman para guru. Sehingga guru-guru mudah dalam mengintegrasikan kurikulum SIT dengan Kurikulum Diknas dalam proses pembelajaran.

\section{KESIMPULAN}

Yayasan Wihdatul Ummah Batusangkar dalam mewujudkan visi yayasan membentuk Lembaga Semi Otonom (LSO) dalam mengelola pendidikan, dan yayasan memposisikan dirinya sebagai penaggungjawab, konseptor dan pengawas. LSO punya wewenang penuh dalam pengelolaan pendidikan tetapi tidak dalam pengangkatan kepala sekolah, pengangkatan guru, pemberhentian guru, penetapan biaya operasional sekolah, masalah pembangunan, dan pengadaan tanah. LSO pendidikan mengayomi tiga lembaga pendidikan yakni Pendidikan Usia Dini (PAUD) Taman Asuh Anak Islam, Taman Kanak Kanak Islam (TKAI) Qurrata A'Yun, dan Sekolah Dasar Islam Terpadu (SDIT) Qurrata A'yun. Agar LSO pendidikan dan unit-unit pendidikan dapat bergerak dan berkembang secara profesional, efektif dan efesien maka yayasan dan LSO pendidikan menyusun buku panduan Sistem Manajemen Tata Kelola Lembaga Semi Otonom (LSO) Pendidikan Tahun 2013. LSO pendidikan menyusun program guna meningkatkan kualitas pendidikan di masing-masing unit. Program tersebut meliputi 1) Program Awal Tahun; 2)
Kegiatan Bulanan; 3) Kegiatan Mingguan; dan 4) Kegiatan Harian. Kemudian membuat RAB, mengembangkan sarana dan prasarana serta melakukan pengawasan dan pengendalian.

\section{KEPUSTAKAAN ACUAN}

Afifuddin. (2010). Bahan Perkuliahan Manajmen Madrasah. Bandung: Pascasarjana UIN Sunan Gunung Jati.

Chatamarrasjid. (2000). Tujuan Sosial Yayasan dan Kegiatan Usaha Bertujuan Laba. Bandung: PT Citra Aditya Bakti.

Direjo, Sartono Karto. (2005). Metode-Metode Penelitian Masyarakat. Jakarta: Grafindo.

Depdiknas. (2012). Manajemen Peningkatan Mutu Pedidikan Berbasis Sekolah (Buku I), Jakarta: Depdiknas.

Hanafi, Mamduh M. (2000). Manajemen. Yogyakarta: UPPAMP YKPN.

Hasibuan, Malayu S.P. (1990). Manajemen Dasar, Pengetian, Dan Masalah. Jakarta: CV. Haji Mas Agung.

Husaini, Usman. (2006). Manajemen Teori, Praktik, Dan Riset Pendidikan. Jakarta: Bumi Aksara.

Mulyasa, E. (2005). Menjadi Kepala Sekolah Profesional. Bandung: PT. Remajda Rosda Karya. 
Pahlawan Kayo, RB. Khatib. (2007). Rohendi, Tjetjep, R. (1992). Analisis Data Manajemen Dakwah Dari Dakwah Kualitatif. Jakarta: UI Pers. Konvensional Menuju Dakwah Profesional. Jakarta: Amzah.

Ritzer, George (2007). Sosiologi Ilmu Pengetahuan Berparadigma Ganda. Diterjemahkan oleh Alimandan. Jakarta: PT Raja Grafindo Persada.

Sukmadinata, Nana Syaodih. (2009). Metode Penelitian Pendidikan. Bandung: PT. Remaja Rosdakarya.

Sukandarrumidi. (2006). Metodologi Penelitian: Petunjuk Praktis Untuk Sistem Manajemen dan Tata Kelola Lembaga Semi Otonom (LSO) Pendidikan Yayasan Pendidikan dan Dakwah Wihdatul Ummah Batusangkar tahun 2013.

Setiawan. (1992). Aneka Masalah Hukum dan Hukum Acara Perdata. Bandung: Alumni.

Undang-Undang Nomor 16 Tahun 2001.

Undang-Undang Nomor 28 Tahun 2004. University Press. 